\title{
PENGARUH KURS RUPIAH, INFLASI DAN SUKU BUNGA TERHADAP RETURN SAHAM PERUSAHAAN SEKTOR JASA SUB KONSTRUKSI DAN BANGUNAN PADA BURSA EFEK INDONESIA
}

\author{
Galih Abi Nugroho', Sri Hermuningsih ${ }^{2}$ \\ Fakultas Ekonomi, Universitas Sarjanawiyata Tamansiswa Yogyakarta \\ gnugroho517@gmail.com, hermuningsih@ustjogya.ac.id
}

\begin{abstract}
ABSTRAK
Penelitian ini bertujuan untuk mengetahui pengaruh kurs rupiah, inflasi dan suku bunga di perusahaan jasa sub konstruksi dan bangunan yang terdaftar di Bursa Efek Indonesia untuk periode 2014-2018. Sifat penelitian ini adalah pendekatan kuantitatif karena data yag digunakan adalah dalam bentuk angka dalam analisis statistic. Populasinya adalah perusahaan konstruksi dan bangunan yang terdaftar di Bursa Efek Indonesia. Sampel yang digunakan adalah data panel, dengan data time series yaitu 5 tahun dan data cross section sebanyak 12 perusahaan. Teknik pengambilan sampel diperoleh denagn teknik purposive sampling. Teknik pengumpulan data menggunakan dokumentasi, sedangkan teknik analisi data menggunakan analisis regresi linier berganda yang didukung dengan uji asumsi klasik yaitu uji normalitas, uji multikoliniearitas, uji heteroskdastisitas dan uji autokorelasi. Dalam penelitian ini juga menggunakan uji Sobel. Berdasarkan hasil analisis data menunjukkan bahwa: (1) Kurs rupiah berpengaruh positif dan tidak signifikan terhadap return saham, (2) Inflasi berpengaruh negatif dan signifikan terhadap return saham, (3) Suku bunga berpengaruh negatif dan signifikan terhadap return saham, (4) Secara simultan, kurs rupiah, inflasi dan tingkat suku bunga berpengaruh signifikan terhadap return saham. Hasil koefisien determinasi $\left(\mathrm{R}^{2}\right)$ sebesar $12.1 \%$ dan sisanya sebesar $87.9 \%$ dipengaruhi oleh variabel lain diluar model.
\end{abstract}

Kata kunci: Kurs Rupiah, Inflasi, Suku Bunga, Return Saham

\begin{abstract}
This study aims to determine the effect of the rupiah exchange rate, inflation and interest rates in sub construction and building service companies listed on the Indonesia Stock Exchange for the 20142018 period. The nature of this research is a quantitative approach because the data used are in the form of numbers in statistical analysis. The population is construction and building companies listed on the Indonesia Stock Exchange. The sample used was panel data, with time series data of 5 years and cross section data of 12 companies. The sampling technique was obtained by using purposive sampling technique. Data collection techniques using documentation, while data analysis techniques using multiple linear regression analysis supported by the classical assumption test that is normality test, multicollinearity test, heteroscedasticity test and autocorrelation test. In this study also used the Sobel test. Based on the results of data analysis, it shows that: (1) Rupiah exchange rate has a positive and not significant effect on stock return (2) Inflation has a negative and significant effect on stock return (3) Interest rates have a negative and significant effect on stock return, (4) simultaneously, rupiah exchange rate, inflation and interest rates have a significant effect on stock return. The results of the coefficient of determination $\left(\mathrm{R}^{2}\right)$ of $12.1 \%$ while the remaining $87.9 \%$ is influenced by other variables outside the model.
\end{abstract}

Keywords: Rupiah Exchange Rate, Inflation, Interest Rates, Stock Return 


\section{PENDAHULUAN}

Perkembangan ekonomi yang terjadi di Indonesia pada pertengahan 1997 mengalami krisis ekonomi, kinerja keuangan khususnya bisnis pasar modal mengalami penurunan yang signifikan bahkan banyak perusahaan yang melakukan penutupan atau gulung tikar. Perkembangan bisnis suatu negara khususnya Indonesia bisa ditinjau dari sudut pandag ekonomi makro ataupun mikro. Dalam sektor makro ekonomi secara keseluruhan dapat dilihat dari aktivitas pasar modal dan industri keuangan pada negara tersebut. Tandenlin (2007) mengungkapkan para investor sebagai pihak yang melakukan investasi dengan pembelian saham di pasar modal akan menganalisis kondisi perusahaan tersebut terlebih dahulu supaya investasi yang dilaksanakan mendapatkan laba atau keuntungan (return). Investor harus memahami situasi dan meramalkan kondisi ekonomi makro negara tujuan invesatsi pada masa mendatang untuk pengambilan keputusan sehinggan investasi tersebut diharapkan mendapatkan keuntungan. Sebagai pemodal atau pemegang dana harus mampu mempertimbangkan banyak indikator yang bisa membantu dalam tahap pembuatan keputusan (Decision Maker). Indikator-indikator makro ekonomi yang banyak digunakan di bursa efek adalah tingkat naik turunnya atau fluktuasi tingkat suku bunga, inflasi dan kurs rupiah.

Faktor penting dalam suatu negara diindikasikan salah satunya dengan suku bunga bank Indonesia karena apabila terjadi perubahan tingkat suku bung maka akan berpengaruh luas dalam ekonomi negara tersebut. Indikator lain yang menjadi acuan untuk para investor dalam pengambilan keputusan berinvestasi adalah inflasi. Inflasi secara umum adalah kejadian atau kecenderungan dimana harga-harga dipasar mengalami perubahan harga yang naik secara terus menerus (Fuadin, 2019). Nilai mata uang akan mempunyai harga jika ditukarkan dengan mata uang negara lain, menurut (Cahyo, 2017) kurs mata uang dapat diartikan sebagai perbandingan antar mata uang ketika, nilai tukar melemah atau terdeprisasi terhadap dollar Amerika Serikat, maka secara otomatis akan mempengaruhi barang-barang khususnya barang yang didatangkan dari luar atau impor. Apabila kenaikan terjadi pada barang impor maka biaya produksi akan mengalami kenaikan sehingga berpengaruh terhadap keuntungan yang semakin berkurang.

\section{METODE PENELITIAN}

\section{A. Sifat Penelitian}

Sifat penelitian yang akan dilakukan ini bersifat kuantitatif, metode kuantitatif adalah pendekatan ilmiah yang memandang satu cara realitas itu dapat diklasifikasikan, konkrit, teramati, terukur, hubungan variabelnya bersifat sebab akibat dan data penelitiannya berupa angkaangka dan analisisnya menggunakan statistic. Penelitian ini diarahkan untuk menguji pengaruh kurs rupiah, inflasi dan tingkat suku bunga terhadap return saham pada perusahaan sub jasa sektor konstruksi dan bangunan yang tercatat di Bursa Efek Indonesia periode 2014-2018.

\section{B. Definisi Operasional Variabel}

\section{Variabel Dependen (Y)}

Return Saham adalah pengembalian hasil atau laba atas investasi modal. Pada penelitian ini return saham dihitung dari laporan keuangan. Perhitungan Return Saham dalam penelitian ini diambil dari hartono (2014) dapat digunakan sebagai berikut:

$$
R_{t}=\frac{P_{t}-P_{t-1}}{P_{t 1}} \times 100 \%=\cdots \%
$$


Keterangan:

$R_{t}=$ Return Saham

$P_{t}=$ Harga saham saat ini

$P_{t-l}=$ Harga saham periode sebelumnya

2. Variabel Independen (X)

a. Suku Bunga BI

$$
\text { Tingkat suku bunga }
$$

yang digunakan dalam penelitian ini adalah tingkat suku bunga SBI rata-rata pertahun yang diperoleh dari penjumlahan suku bunga SBI perbulan selama setahun kemudian dibagi dua belas yang diambil dari periode tahun 2008-2014.

b. Inflasi

Tingkat inflasi yang digunakan dalam penelitian ini adalah tingkat inflasi Indonesia yang diperoleh dari www.bi.go.id selama tahun 2008-2014. Tingkat inflasi yang digunakan adalah dalam tingkat inflasi perbulan selama setahun, kemudian dibagi 12 (dua belas).

c. Kurs Rupiah

Kurs Rupiah yang akan diteliti adalah nilai tukar rupiah terhadap dollar Amerika Seikat sebagai acuan mata uang seluruh dunia. Pengambilan data kurs rupiah dari situs www.bi.go.id. Data yang digunakan dalam penelitian adalah nilai kurs jual akhir bulan selama periode pengamatan antara tahun 2014 - 2018 kemudian dijumlahkan dalamm setahun dan dibagi 12 (dua belas).

\section{Populasi dan Sampel}

Penelitian ini menggunakan data sekunder. Populasi dalam penelitian ini adalah perusahaan sektor Industri Barang Konsumsi yang terdaftar di BEI pada periode 2014-2018, dan sampel penelitian ini menggunakan teknik purposive sampling.

\section{HASIL DAN PEMBAHASAN}

\section{A. Uji Asumsi Klasik}

Sebelum dilakukannya pengujian hipotesis terlebih dahulu dilakukan pengujian asumsi klasik, agar hasil dari penelitian ini valid dan tidak menyebabkan hasil yang bias.

1. Berdasarkan hasil pengujian Kurs Rupiah, Inflasi dan Suku Bunga terhadap Return Saham menunjukkan hasil signifikan 0.794 diatas tingkat signifikansi 5\%. Pengujian Kurs Rupiah, Inflasi dan Suku Bunga terhadap Return saham menunjukkan hasil 0.794 diatas tingkat signifikansi $5 \%$.

2. Uji Multikoliniearitas

Berdasarkan hasil pengujian Kurs Rupiah terhadap Return Saham menunjukkan hasil tolerance 0.600 dan VIF 1.668, Inflasi terhadap Return Saham menunjukkan hasil tolerance 0.437 dan VIF 2.288, Suku Bunga terhadap Return Saham menunjukkan hasil tolerance 0.657 dan VIF 1.523. Berdasarkan hasil tersebut disimpulkan bahwa tidak terjadi Multikoliearitas.

3. Uji Heteroskedastisitas

Berdasarkan hasil pengujian Kurs Rupiah, Inflasi dan Suku Bunga terhadap Return Saham menunjukkan hasil signifikan $0.226,0.311$ dan 0.889 diatas tingkat signifkansi $5 \%$, maka dapat disimpulkan tidak terjadi Heteroskedastisitas. Berdasarkan hasil tersebut disimpulkan bahwa tidak terjadi Heteroskedastisitas. 
4. Uji Autokorelasi

Pengujian Kurs Rupiah, Inflasi, dan Suku Bunga terhadap Return Saham menunjukkan hasil 0.253 diatas signifikansi 5\%, maka dapat disimpulkan bahwa tidak terjadi Autokorelasi.

5. Hasil Analisis Regresi Linear Berganda menggunakan Uji-t.

Berdasarkan hasil Uji-t diperoleh hasil sebagai berikut:

Tabel 1. Hasil Uji-t Dividend Payout Ratio

\begin{tabular}{llll}
\hline \multicolumn{4}{l}{ Coefficients $^{\mathrm{a}}$} \\
\hline Model & & & \\
& $\mathrm{B}$ & $\mathrm{t}$ & Sig. \\
\hline $\begin{array}{l}\text { (Constant) } \\
\text { Kurs }\end{array}$ & -19.415 & -1.031 & .307 \\
$\begin{array}{l}\text { Rupiah } \\
\text { Inflasi }\end{array}$ & -1.175 & 1.481 & .144 \\
$\begin{array}{l}\text { Suku } \\
\text { Bunga }\end{array}$ & -.204 & -3.231 & .002 \\
\hline
\end{tabular}

Berdasarkan hasil olah data variabel Kurs Rupiah memiliki nilai Beta sebesar 2.175 hal ini berarti Kurs Rupiah memiliki pengaruh yang positif terhadap Return Saham. sedangkan nilai signifikansi $(0,144>0,05)$ hal ini berarti Kurs Rupiah berpengaruh posoitif tidak signifikan terhadap Return Saham. Jadi, Kurs Rupiah berpengaruh Positif dan tidak signifikan terhadap Return Saham. Dengan demikian $H 1$ (Kurs Rupiah BI berpengaruh negatif terhadap Return Saham) ditolak.

Berdasarkan hasil olah data variabel Inflasi memiliki nilai Beta sebesar -1.169 hal ini berarti Inflasi memberikan pengaruh yang negatif terhadap Return
Saham. Sedangkan nilai signifikansi $(0,002<0,05)$ hal ini berarti Inflasi memiliki pengaruh yang signifikan. Sehingga dapat ditarik kesimpulan bahwa Inflasi memiliki pengaruh yang negatif dan signifikan. Dengan demikian H2 (inflasi berpengaruh negatif terhadap Return Saham) diterima.

Berdasarkan hasil olah data variabel Suku Bunga memiliki nilai beta sebesar -0.204 hal ini berarti bahwa Suku Bunga memiliki pengaruh yang negatif terhadap Return Saham. Sedangkan nilai signifikansi ( 0 . $025<0,05)$ hal ini berarti Suku Bunga berpengaruh negatif secara signifikan terhadap Return Saham. Jadi, Inflasi berpengaruh negatif dan signifikan terhadap Return Saham. Dapat ditarik kesimpulan bahwa H3 (Suku Bunga berpengaruh secara signifikan terhadap Return Saham) diterima.

\section{B. Pembahasan}

1. Pengaruh Kurs Rupiah terhadap Return Saham

Berdasarkan hasil olah data variabel Kurs Rupiah memiliki nilai beta sebesar 2.175 hal ini berarti bahwa Kurs Rupiah memiliki pengaruh yang positif terhadap Return Saham. Sedangkan nilai signifikansi $(0,144<0,05)$ hal ini berarti Kurs Rupiah tidak memiliki pengaruh signifikan terhadap Return Saham.

2. Pengaruh Inflasi terhadap Return Saham

Berdasarkan hasil olah data variabel Inflasi memiliki nilai Beta sebesar -1.169 hal ini berarti Inflasi memberikan pengaruh yang negatif terhadap Return 
Saham. Sedangkan nilai signifikansi $(0,002<0,05)$ hal ini berarti Inflasi memiliki pengaruh yang signifikan. Sehingga dapat ditarik kesimpulan bahwa Inflasi memiliki pengaruh yang negatif dan signifikan. Dengan demikian H2 (inflasi berpengaruh negatif terhadap Return) diterima.

3. Pengaruh Suku Bunga terhadap Return Saham

Berdasarkan hasil olah data variabel BI Rate/Suku bunga BI memiliki nilai Beta sebesar 0,204 hal ini berarti Suku Bunga memiliki pengaruh yang negatif terhadap Return Saham. Sedangkan nilai signifikansi $(0,025<0,05)$ hal ini berarti Suku Bunga berpengaruh secara signifikan terhadap Return Saham. Jadi, Suku Bunga berpengruh negatif dan signifikan terhadap Return Saham. Dengan demikian H3 (Suku Bunga BI berpengaruh negatif terhadap Return Saham) diterima. Hasil penelitian ini menunjukkan bahwa nilai Suku Bunga sangat layak diperhitungkan dalam memprediksi Return Saham. Tingkat kenaikan Suku Bunga yang di atur oleh pemerintah akan memberikan dampak yang signifikan terhadap pergerakan Return Saham. Ketika Suku Bunga naik maka akan membuat Return Saham mengalami penurunan yang signifikan.

4. Pengaruh Kurs Rupiah, Inflasi dan Suku Bunga terhadap Return Saham

Hasil pengujian uji $F$ menunjukan bahwa nilai $F$ sebesar 3.714 dan nilai signifikansi adalah 0,017. Karena nilai signifikansi lebih kecil dari 0,05 maka terdapat pengaruh yang signifikan variabel Kurs
Rupiah, Inflasi dan Suku Bunga secara simultan terhadap Return Saham. Hasil nilai koefisian determinasi $\left(\mathrm{R}^{2}\right)$ sebesar $12.1 \%$ sedangkan sisanya $\quad 87.9 \%$ dipengaruhi oleh variabel lain diluar model regresi.

\section{KESIMPULAN DAN SARAN}

\section{A. Kesimpulan}

Berdasarkan hasil pembahasan analisis data melalui pembuktian terhadap hipotesis mengenai permasalahan yang diangkat mengenai faktor-faktor yang mempengaruhi Return Saham. Maka dapat diambil kesimpulan dari penelitian ini sebagai berikut:

1. Kurs Rupiah menunjukkan nilai Beta sebesar 2.175 dengan taraf signifikan 0.144 . Taraf signifikansi hasil sebesar 0.144 tersebut lebih besar dari 0,05 sehingga H1 (Suku Bunga BI berpengaruh positif terhadap Return Saham) ditolak.

2. Variabel Inflasi memiliki nilai Beta -1.169 dengan nilai signifikansi $(0.002<0.05)$. Sehingga dapat ditarik kesimpulan bahwa Inflasi berpengaruh negatif dan berpengaruh secara signifikan terhadap Return Saham. Sehingga H2 (Inflasi berpengaruh negatif terhadap Return Saham) diterima.

3. Variabel Suku Bunga memiliki nilai Beta sebesar -0.204 hal ini berarti Suku Bunga berpengaruh negatif terhadap Return Saham. Variabel Suku Bunga memiliki nilai signifikansi $(0,044<0,05)$ Suku Bunga berpengaruh secara signifikan terhadap Return Saham. Sehingga H3 (Suku Bunga berpengaruh secara signifkan terhadap Return Saham) diterima. 
4. Karena nilai signifikansi 0,017 lebih kecil dari 0,05 maka secara simultan variabel Kurs Rupiah, Inflasi dan Suku Bunga berpengruh signifikan terhadap Return Saham. Dapat ditarik kesimpulan H4 (Kurs Rupiah, Inflasi dan Suku Bunga berpengaruh signifikan terhadap Return Saham) diterima.

\section{B. Keterbatasan Penelitian}

1. Penelitian ini hanya menggunakan tiga variabel independen yaitu Kurs Rupiah, Inflasi dan Suku Bunga dalam pengaruhnya terhadap variabel dependen yaitu Return Saham.

2. Tidak menggambarkan perubahan Return Saham perhari karena data yang diambil untuk diteliti adalah Tahunan.

3. Masih banyak faktor yang mempengaruhi Return Saham selain variabel Independen yang diteliti.

\section{Saran}

1. Peneliti berikutnya disarankan untuk lebih banyak menggunakan faktor lain selain yang sudah diteliti.

2. Menambah periode pengamatan untuk menghasilkan informasi yang lebih baik.

3. Masih banyak faktor lain yang dapat mempengaruhi Return Saham seperti faktor ekonomi makro dan faktor ekonomi mikro.

\section{DAFTAR PUSTAKA}

Akbar, F. (2013). Pengaruh Inflasi, Suku Bunga dan Nilai Tukar Rupiah terhadap Return Saham di Bursa Efek Indonesia, 66.

Arista, D. (2012). Analisa Faktor-Faktor yang Mempengaruhi Return Saham
(Kasus pada Perusahaan Manufaktur yang Go Public di BEI Periode Tahun 2005 - 2009). Jurnal Ilmu Manajemen dan Akuntansi Terapan, 3, 1-15.

Cahyo, D.L. (2017). Pengaruh Rasio Keuangan terhadap Return Saham.

Dianita. (2019). Pengaruh Inflasi, Nilai Tukar, Suku Bunga terhadap Risiko Sistematis pada Perusahaan SubSektor Food and Beverage di Bursa Efek Indonesia. Dianita, 8(10), 116130.

Fuadin, N. (2019). Pengaruh Suku Bunga BI, Inflasi dan Kurs Rupiah terhadap Indeks Harga Saham Gabungan pada Bursa Efek Indonesia (Periode Tahun 2013-2017). 373-426.

Nur, F.S. (2012). Analisis Pengaruh DER, CR, ROE dan TAT terhadap Return Saham. Skripsi Universitas Diponegoro Semarang.

Wiyono, G. (2011). Merancang Penelitian Bisnis dengan alat analisis SPSS \& SmartPLS.

Zuleli, R., \& Wulansari, Y.M. (2014). Pengaruh Tingkat Keuntungan Pasar, Nilai Tukar Rupiah, Inflasi dan Tingkat Suku Bunga terhadap Return Saham Industri. Jurnal Wawasan Manajemen, 1(1). 